\title{
Indigenous People, Organized Crime and Natural Resources: Borders, Incentives and Relations
}

\author{
Daan P. van Uhm ${ }^{1} \cdot$ Ana G. Grigore ${ }^{1}$
}

Accepted: 24 July 2021 / Published online: 10 August 2021

(c) The Author(s) 2021

\begin{abstract}
This article explores the relationship between the Emberá-Wounaan and Akha Indigenous people and organized crime groups vying for control over natural resources in the Darién Gap of East Panama and West Colombia and the Golden Triangle (the area where the borders of Laos, Myanmar (Burma), and Thailand meet), respectively. From a southern green criminological perspective, we consider how organized crime groups trading in natural resources value Indigenous knowledge. We also examine the continued victimization of Indigenous people in relation to environmental harm and the tension between Indigenous peoples' ecocentric values and the economic incentives presented to them for exploiting nature. By looking at the history of the coloniality and the socioeconomic context of these Indigenous communities, this article generates a discussion about the social framing of the Indigenous people as both victims and offenders in the illegal trade in natural resources, particularly considering the types of relationships established with dominant criminal groups present in their ancestral lands.
\end{abstract}

\section{Introduction}

Organized crime groups thrive in remote areas with little state presence (Blok 1974; Gambetta 1993). In such regions lacking governmental institutions and law enforcement, illegal activities may flourish and affect the lives of local people, including Indigenous people. The socioeconomic context of Indigenous people may make them especially vulnerable to violent crime actors vying for control over natural resources. In this article, we explore how Indigenous people relate to organized crime groups present in their territories. Although the over-representation of Indigenous people in the penal system has been analyzed critically (see, e.g., Anthony 2013; Broadhurst 2002) and the victimization of Indigenous people during armed conflict has been examined by several studies (see, e.g., Cunneen 2007), the relationship between Indigenous people and organized crime remains an understudied topic.

Daan P. van Uhm

D.P.vanUhm@uu.nl

1 Willem Pompe Institute for Criminal Law and Criminology, Utrecht University, Utrecht, The Netherlands 
This article is based on empirical research conducted in Darién, the border area of Panama and Colombia, and in the Golden Triangle, where Laos, Myanmar (Burma), and Thailand meet. Interviews with the Indigenous people of Emberá-Wounaan in Darién and the Akha in the Golden Triangle were undertaken to understand the diversification of organized crime groups into the illegal trade in natural resources, including the local context of organized crime and its relationship with the Indigenous communities. ${ }^{1}$ During fieldwork between 2017 and 2020, we conducted participant observation in areas where Indigenous people live, including areas where deforestation, mining and poaching occur, and where cocaine and opium are grown. Inspired by Cunneen and Tauri's (2016) critique of orthodox criminology for adopting a top-down approach to research on Indigenous people, this article draws on fieldwork conducted "from within" Indigenous communities to bring forward issues they face in relation to organized crime in their territories. Nonetheless, it must be acknowledged that conducting research from the Global North on the Global South has the risk of imposing a reality that is constructed through a different lens (see, e.g., Grosfoguel 2007; Sollund and Runhovde 2020).

This article is divided into three parts. The first part, "The Southern Criminology and Green Criminology Nexus," offers a discussion of the theoretical frameworks of southern and green criminologies, noting the criminalization of marginalized communities, (environmental) crimes and harms, and the role of Indigenous perspectives in criminology. The second part, "Historical Context," introduces the colonial practices of land grabbing, displacement and violence to which both Emberá-Wounaan and Akha Indigenous people have been subjected in the past centuries, as well as the emerging role of organized crime in these territories. The final part, "Borderlands, Indigenous People and Crime," presents empirical findings about why organized crime groups have sought Indigenous knowledge, the tensions between the ecophilosophies of Indigenous communities and the economic incentives for the exploitation of nature, and the different relationships between organized crime groups and the Indigenous people among whom they live. We conclude with a discussion on the Indigenous people as both offenders and victims of the trade in natural resources.

\section{The Southern Criminology and Green Criminology Nexus}

The colonial past of modern states has created a metaphorical divide between the Global North and the Global South-one which transcends geographical boundaries by dividing the world into "developed" and "developing" (Carrington et al. 2016: 5 (emphasis in original)). The two are mutually constructed subjects in an historical context of colonial rule from which the Global South emerged with an economic and political situation influenced by unequal relationships with the Global North (Carrington et al. 2018, 2019; Cunneen and Tauri 2017). This divide is also visible through the presumed Northern "normative

\footnotetext{
1 Between 2017 and 2020, the first author conducted more than twenty-five interviews with Indigenous people with the help of local interpreters. In certain territories, he needed permission from the dominant groups, such as criminal rings, paramilitaries or guerrillas, to enter their areas. This was accomplished by establishing contact with gatekeepers in the field. The two case studies are analyzed simultaneously because the Indigenous people in these regions share both a common history of colonial intervention and similar ecophilosophies despite their geographical location relative to one another. Yet, differences emerged in the way they relate to the organized crime groups.
} 
benchmark (the developmental destination) to which the rest of the world ... naturally aspire[s]" (Carrington et al. 2016: 5). This presents the Global North as the holder of objective truth and creator of meaning, whereas the Global South, and particularly Indigenous knowledge, is dismissed for relying on subjective or "folk" epistemology (Cunneen and Tauri 2016; Grosfoguel 2007). From a Southern theoretical perspective, Connell (2007) has critiqued such normative standards for acting as universal knowledge descriptive of both the colonizing and the colonized worlds, for seeing the world through the eyes of the Global North rather than through the "metropole's [here, the North's] action on the rest of the world," for excluding Southern knowledge from the general scientific discourse, and for the act of "grand erasure" of the experiences of the other (Connell 2007: 45-46).

Global North-Global South inequalities are also reflected in the efforts of green criminology to address the lack of attention to the dialectal relationship between humans and their natural environment, as well as to the environmental harms to ecosystems, plants, humans and non-human animals (see, e.g., Sollund 2019; South 2007; Van Uhm 2016; White 2011). Benton (1998) has pointed out the flaws in the dualistic strategy of thinking about nature and society as separate kingdoms, in which human society plays an independent role. Lynch and Stretesky (2014) have articulated the consequences of "ecological disorganization" in which continuous production is responsible for disturbing the ecological balance (see also Lynch et al. 2018; Ruggiero and South 2013; Van Uhm 2018). In particular, the rampant economic growth of Global Northern states is responsible for this ongoing harm to nature in Global Southern states (Beirne and South 2007; Duffy 2010; Goyes 2019). Therefore, the unequal distribution of environments "among peoples in terms of access to and use of specific natural resources in defined geographical areas, and the impacts of particular social practices and environmental hazards on specific human populations (for example, as defined on the basis of class, occupation, gender, age, ethnicity)," along with the health and wellbeing of the natural environment, is relevant from perspectives of environmental and ecological justice (White 2014: 43).

Southern criminology and green criminology share similar notions of harm and victim. Both emphasize the importance of considering harm rather than just crime to show that actions can create victims regardless of the legal classification of a given act. Because predominant economic interests in natural resources have long hampered criminalization processes of harm to the environment (Lynch and Stretesky 2014; Ruggiero and South 2013), green criminology is concerned with both human and non-human victims of environmental crime and harm (Brisman and South 2020; Sollund 2019; Van Uhm 2015; White 2011). In addition, southern criminology addresses the victimization of marginalized people, such as Indigenous communities - an effort to respond to the limited understanding of mainstream criminology of the perpetual impact of colonization on criminal justice systems (Cunneen 2018). A result of this can be seen in the monopolization of people-the subjugation of one group of people by another in "unapologetically racist" ways for economic expansion, primarily driven by unequal power relations (Goyes 2019: 112). Related to this is the ecological discrimination that occurs through "systematic negative differentiation and oppression of some human groups, non-human animals and ecosystems, based on modern instrumental ideas about how to treat and relate to the natural environment" (Goyes 2019:15).

From both perspectives, Indigenous people have been affected by the Global North-Global South divide due to structural inequality. Cunneen and Tauri (2016, 2017) propose an Indigenous perspective for criminology that recognizes the common experience of European colonization and marginalization shared by Indigenous communities despite varying cultural, linguistic, political or religious differences between them. Building on that work, Cunneen (2018: 19-20) identifies three main 
challenges-namely, acknowledging (1) the role of colonialism and of coloniality of power in understanding how Indigenous groups have been shaped as the "other"; (2) the role of epistemic violence as the "active denial, the delegitimization, the suppression and eradication of other ways of knowing" on behalf of Northern powers; and (3) the role of Indigenous people as political actors, particularly in the context of post-colonial criminal justice systems. In this framework, the coloniality of power refers to the systematic racial and cultural division caused by European colonialism, which led to a restructuring of local societies according to Eurocentric knowledge (Quijano 2000). Addressing these issues can show that "the over-representation of Indigenous people in crime and victimization statistics needs to be contextualized within a much broader framework of the effects of colonization" (Cunneen and Tauri 2016: 46; see also Broadhurst 2002). Moreover, it becomes apparent that Indigenous people are both the offenders and victims of criminal justice systems because of their often-limited understanding about the perpetual impact of colonization (Broadhurst 1999; Cunneen 2018).

In addition to contemplating the colonial influences on Indigenous people, this article also considers how the fight for power over natural resources in two post-colonial Indigenous borderlands has been dominated increasingly by organized crime groups using violence and intimidation. It is, therefore, important to understand how Indigenous people relate to the "new" form of territorial control. Organized crime groups may go as far as acting as alternative governments in areas in which state presence is weak or nonexistent, and they can use extortion, taxation and violence for gaining social and territorial control (Gambetta 1993; Varese 2001). These groups eventually replace legitimate protectors and become involved in supplying private protection (Paoli 2003; Varese 2011). Moreover, the social embeddedness of crime reflects how organized crime groups interact with their social environment (Kleemans and van de Bunt 1999; van de Bunt et al. 2014). According to Passas (2002), such relationships between actors-in this case, Indigenous communities and organized crime groups-can be either symbiotic or parasitical. For example, a symbiotic relationship can take the form of collaboration or reciprocity, whereas a parasitical relationship is an antithetical or opposing one (Passas 2002).

\section{Historical Context}

Throughout history, the Indigenous groups in both Darién and the Golden Triangle have been subjected to colonial practices that have resulted in systematic racial and cultural divisions. Despite differences between these two Indigenous peoples, they share similarities in terms of their experiences of criminalization and marginalization. By addressing the coloniality of power that altered significantly the lifestyles of the Indigenous groups of Emberá-Wounaan in Darién and the Akha in the Golden Triangle, we explain their experiences of historical oppression and violence and prioritize Indigenous perspectives to counteract mainstream criminological understandings of crime and Indigenous people. 


\section{The Emberá-Wounaan in Darién}

The Darién Gap in Central America - at the border between Panama's Darién Province and Colombia's Chocó Department-is a large watershed, jungle and mountainous region representing a break in the Pan-American Highway that extends from Alaska to the lower reaches of South America (Gisborne 1853; Reclus 1881). The Darién Gap is populated by the Emberá and Wounaan Indigenous people living along the upper tributaries of the Tuira, Chucunaque, Sambú and Atrato Rivers. They account for 34.6 percent of the total population of Darién Province in Panama, while "about 8.5 percent of Chocó Department's population [in Colombia] is Indian" (Suman 2007: 560; see also Velásquez Runk 2007). ${ }^{2}$ Traditionally, the Emberá-Wounaan have lived in thatched huts, have used dugout canoes to navigate rivers, and have fashioned blowguns, bows and spears as hunting weapons (Myers et al. 1978; Nordenskiöld 1928; Reverte Coma 2002). In the past, no formal chiefs, councils, or leaders existed, but currently, most Emberá-Wounaan villages have adopted a social and political organization with chiefs and village leaders (Herlihy 1986; Theodossopoulos 2016).

Colonial violence in Darién began in the early 1500s, when Spanish colonizers, in search of new territory and natural resources, "discovered" the Indigenous lands of present-day Colombia and Panama (Sauer 1966). In 1509, they established the first "New World" mainland colony, "christening it Santa María La Antigua de Darién" (Velásquez Runk 2017: 35). This was a type of settler colonialism that focused on securing land and natural resources by asserting sovereignty in the form of "discovery" of the land, legitimized on the basis of a "civilizing mission" to bring Christianity to Indigenous territories (Cunneen and Tauri 2016). The region was soon known for the gold mines of Cana- "the richest gold mines ever yet found in America" (Anderson 1911: 17). The Emberá-Wounaan communities, however, put up a fierce defense of their territory and culture, which culminated in significant losses. Throughout the seventeenth and eighteenth centuries, Darién became a vulnerable area with competing colonizers, Indigenous tribes and pirates (Velásquez Runk 2017).

The methods that Spaniards used to subdue and control Indigenous populations varied over time, but eventually, "the use of force, [was] the only method that ultimately succeeded in pacifying a population whose continuing resistance prevented Spanish settlers from exploiting the valuable resources" (Williams 1999: 399). Control over the area became essential for colonial expansion, as gold mining and logging became prominent activities in Darién; in doing so, however, it also resulted in racial divisions (Goldman 1920; Sauer 1966). The Spaniards brought African slaves to Darién to work, maintain the ships, and transport and protect the gold (Heckadon-Moreno 1997). Unsurprisingly, clashes between Indigenous groups and the colonizers arose and resulted in displacement, land grabbing and violence (Töller 2009; Velásquez Runk 2007). Spanish colonialism manifested itself through a monopoly over people and natural resources. The latter could be seen as a form of accumulation by dispossession as wealth and power were centralized in the hands of a few, accomplished by dispossessing public and private entities of their wealth and land (Harvey 2003). Eventually, the political and economic developments that ended the colonial rule created a power vacuum in the Darién territory.

\footnotetext{
2 The two groups are often mistaken for one another and they have been known as "Chocó Indians" or "Chocoes," with similar languages and cultural practices (Velásquez Runk 2017).
} 
Since the 1960s, Colombia has been the battleground of an asymmetric armed conflict that has involved the Colombian government, paramilitaries, guerrillas and organized crime groups vying for territorial control (Idler 2019; Thoumi 1995). As the cocaine industry exploded, drug traffickers began investing and laundering their windfall drug profits by buying up huge expanses of rural property in Darién (Ballvé 2020). Even though Indigenous populations had been growing coca and chewing the leaves for hundreds of years, with the "discovery" of cocaine by the North, Indigenous groups were enticed or forced by violent groups to become involved in the business (Karch 1999; Thoumi 1995). From the late 1990s onwards, the political situation in Colombia and the growing global demand for cocaine resulted in rising conflicts between paramilitaries, guerrillas and drug cartels; many Indigenous people were killed, several kidnappings took place, and violence became endemic in the region (Velásquez Runk 2017). Moreover, the controversial Colombian government's coca spraying program during the so-called "War on Drugs" seriously affected Emberá-Wounaan communities through contamination of water and crops, causing community members to fall sick. While repressive policies regarding drug trafficking became central to international efforts, organized crime groups diversified into the lucrative business of gold mining, tropical timber harvesting, and trade in endangered species, alongside their traditional activities (Rettberg and Ortiz-Riomalo 2016; Van Uhm and Nijman 2020). These markets shaped new relations between the Indigenous groups and organized crime groups with regard to the natural resources in their ancestral lands.

\section{The Akha in the Golden Triangle}

The Golden Triangle is the area where Laos, Myanmar (Burma) and Thailand meet at the confluence of the Ruak and Mekong rivers in Southeast Asia (Forbes 1997). When it comes to trade and trafficking activities, however, the name, "Golden Triangle," is often used to refer to a much larger area, including border regions between North Thailand, East Myanmar, Northwest Laos and South China (Chin 2009; Walker 1999). The Golden Triangle gained notoriety in the 1920s as one of world's largest opium producers (Lintner 1994; McCoy 1972), but it was also known for its abundance of jade, rubies, silver, teak and rare animal products (Forbes 1997).

The area is home to a wide range of highland Indigenous groups, among which is the Akha, originating from Tibet and China's Yunnan Province, who are estimated to exceed 600,000 people. ${ }^{3}$ The Akha engage in terrace farming (Tooker 2012), but hunting animals and opium use are also an integral part of their cultural traditions (Bernatzik 1970). Previous generations of Akha used crossbows for bigger animals, but nowadays, they prefer rifles and traps to kill bears, big cats and deer, as well as smaller animals, such as bamboo gophers, civets and pangolins (Goodman 1997). Due to these traditions and knowledge of the highlands, the Akha were subjected to external pressures; for example, in pre-modern times, local rulers oppressed these highlanders and forced them into servitude (Formoso 2010). The economy of lowland states was fuelled by the valuable products from the highlanders, such as aromatic weeds, medicinal herbs, opium and wildlife products (Formoso 2010). The Akha, however, did not benefit from these trades. Instead, Chinese traders, and, later, Western colonizers, profited (Bernatzik 1970; Forbes 1997; Renard 1996).

Throughout the nineteenth and twentieth centuries, the Akha encountered waves of colonization from the British in what was then "Burma," and the French in Laos (Goodman

${ }^{3}$ See http://www.akha.org/. 
1997). Similar to the experience of the Emberá-Wounaan in Darién, the Akha communities were subjected to land grabbing, displacement, and violent "civilizing missions" during the nineteenth century (Williams 2020). Moreover, their territories became the breeding ground for opium production for export under the control of colonial powers (Goodman 1997; Williams 2020). Opium production increased significantly in the Golden Triangle in the twentieth century insofar as inhabitants of some Akha villages even neglected all agriculture other than the cultivation of poppies (Goodman 1997). Gradually, both the trade, itself, and opium addiction among Akha communities increased (Suwanwela 1979). Later, opium production not only reflected the economic influence of the British and French Empires, but it also created sociocultural disparities among the populations. Opium policy in British-ruled Burma provided that "consumption was permitted to those groups whose consumption was linked with productivity, and forbidden to those whose consumption corresponded to crime, unemployment and social instability" (Wright 2014: 152). This set the path for racial and ecological discrimination as the local people were restricted from using and producing opium, while the colonizers were considered the "legitimate" cultivators and traders based on cultural norms (Goyes 2019; Wright 2014).

After independence from Britain and France, respectively, Burma and Laos implemented laws or signed treaties regulating drug production. They did not, however, have the means to enforce such regulations: the region seemed almost lawless with non-state armies and organized crime groups fighting for territory and power (Renard 1996). In addition, the organized crime groups and non-state armed actors who had filled the power vacuum following the end of colonial rule engaged in the drug trade (opium) and wildlife trade (e.g., ivory, pangolin scales, tiger bones and skins). The shift from historically "legitimate" opium cultivation or hunting among the Akha people to "illegitimate" drug production and poaching could be seen as the result of international regulations that criminalize Southern practices for contradicting Northern standards (see generally Cunneen 2008; Grosfoguel 2007; Sollund and Runhovde 2020). This resembles the broader efforts to criminalize drug consumption based on the assumption that drugs are inherently evil, irrespective of the local and historical contexts in which drugs have been used (see Coomber and South 2004). As such, Akha communities' view of the trade in natural resources has been influenced by socially constructed norms through processes of colonization.

\section{Borderlands, Indigenous People and Crime}

The geopolitical and socioeconomic history of land grabbing, displacement, violence, criminalization and control over natural resources in Darién and the Golden Triangle has influenced the social and environmental conditions of the Indigenous people in both areas. In the last decennia, the Emberá-Wounaan communities have experienced armed conflict and militarization on their lands due to powerful groups, such as paramilitaries, guerrillas, and organized crime rings, all vying for territorial control. Similarly, the Akha have lived in the middle of clashes between militia groups, organized crime groups involved in the opium business, and the Burmese and Lao armies. From drugs to deforestation, gold mining and wildlife trafficking, criminal groups have impacted the lives of Indigenous people in the Darién Gap and the Golden Triangle (Ballvé 2020; Chin 2007).

In this part, we describe the different relationships between Indigenous people and organized crime groups. As we attempt to demonstrate, the inclusion of Indigenous epistemologies and ontologies is important to counteract Northern perspectives. Indigenous 
people, as political actors, are engaged in a variety of activities within and against existing (colonizing) criminal justice systems, and we discuss how they interact and negotiate with dominant criminal actors in their living areas, as well as how they interpret legal and illegal boundaries. First, we describe how, geographically, borderlands are particularly attractive to criminal groups for trafficking. We discuss how the Indigenous people living in the border areas of Darién and the Golden Triangle perceive the national borders as artificial boundaries but also have essential knowledge about the area, which makes them ideal for recruitment by organized crime groups. Second, we describe how the Emberá-Wounaan and Akha people live in biodiversity hotspots and have traditionally been depended on their relationship with nature. Even though the ecophilosophies of the Indigenous groups lead them to consider themselves part of nature, socioeconomic incentives to cooperate with organized crime groups may influence and encourage anthropocentric decisions. Third, we consider the coexistence of the Indigenous communities and organized crime groups in both symbiotic and antithetical relationships, from collaboration and reciprocity to parasitism, in order to reveal their myriad interactions.

\section{Artificial Borders: Indigenous Knowledge and Recruitment}

International borders that cut through Indigenous peoples' lands exist as a product of colonization and de-colonization and have thus created a new category of transnational Indigenous peoples (Koivurova 2010). Long before the arrival of the first Europeans in the isthmus of the Americas and before they crossed the Mekong River through the Golden Triangle, Indigenous tribes interacted freely (Goodman 1997; Velásquez Runk 2017). They are now, however, "separated and sometimes face criminal prosecution for keeping traditions practiced for time immemorial" (Osburn 2000: 471). In both case studies, borders are a crucial element in the trade of illegal goods. For states, they represent a political demarcation that helps regulate trade and divide people based on their motivation for crossing it (Osburn 2000), whereas for organized crime groups, borders are important in controlling the trafficking of goods from one country to another (Idler 2019). For the Indigenous communities, however, these borders often have no ontological reality: "they [are] separated by an artificial line created by outside forces" (Osburn 2000: 479), which threatens to transform social and cultural norms by limiting a type of migration otherwise ingrained in Indigenous cultures (Singleton 2009).

Historically, the Emberá-Wounaan have lived in the Darién jungle, which is now split by the Panama-Colombian border. This demarcation, however, is more of a social construct separating Indigenous communities and their families than a physical reality (Alvarado 2002). It does not prevent the Indigenous people from using their knowledge of the territory to cross it, as explained by a Wounaan chief in Katíos National Park in Colombia. All kinds of goods (both legal and illegal) are traded between the villages. For example, young Emberá pick up several kilograms of cocaine at night from organized crime groups in Acandí and walk two days through the jungle to an Emberá village in Panama in order to earn money. Others guide migrants from Acandí through the jungle to Panama, explained a former drug mule and migrant smuggler who grew up in the Emberá village of Nazareth. This Emberá individual clarified that there is a lack of legitimate opportunities for work and Indigenous people are seen as the masters of the Darién jungle who know the environment without getting lost. Therefore, organized crime groups recruit young people belonging to Emberá-Wounaan communities to smuggle drugs, guide migrants, or transport illegal timber, which 
demonstrates that the Indigenous geographic knowledge of the area is crucial in facilitating trafficking.

Similarities can be observed in the case of the border area between Laos, Myanmar (Burma) and Thailand - the region in which the Akha people live. For example, the border between the Golden Triangle countries is demarcated by the Mekong River. Historically, the upper-Mekong villages of Laos, Myanmar (Burma) and Thailand have been involved in different trading activities, including drug (opium) and wildlife trafficking. Informants from nearby Akha communities explained that the tropical forests on either side of the river allow Indigenous people to cross the river unseen. A representative of an Akha community in a mountainous village in northern Thailand explained that the border is rather artificial because the Akha have social lives on both sides of the mountains and a lot of trade flows across the national boundaries. Informants from an Akha community in the Shan State in Myanmar (Burma) echoed that smuggling usually happens at night by small boats across the Mekong River to avoid patrolling boats, but not incidentally, Akha men are arrested or killed by the police forces for smuggling contraband across the borders.

This illustrates how the geographical knowledge of the border areas is important, especially in remote regions with large jungles, river networks and no paved roads. The Indigenous peoples in both case studies become attractive guides for organized crime groups interested in cross-border smuggling of cocaine or valuable timber species in the Darién Gap and trafficking opium or endangered wildlife species in the Golden Triangle. As described above, informants from Akha and Emberá-Wounaan communities refer to the national borders as boundaries created by "outsiders." A Noko, or chief, of the Emberá village Matuganti at the Colombia-Panama border explained that his tribe considers itself to be a part of nature, which helps to understand how community members interpret national boundaries. He clarified that ancestors and spirits, as well as animals and plants, and the Emberá, themselves, are all part of a universal world of sentient beings. Just beyond the central community where the Emberá reside is the forest upriver, where other tribal groups, animals and spirits are located, illustrating the environmental relationships across national boundaries (Herlihy 1986; Koller-Armstrong 2009). The interplay between such ecological beliefs and the prevalence of environmental crimes on Indigenous territories is explained in the following sections.

\section{Biodiversity Hotspots: Ecophilosophies and Economic Incentives}

Both groups of Indigenous people - those living in Darién and those in the Golden Triangle-view humans and nature as "part of an extended ecological family that shares ancestry and origins" (Salmón 2000: 1327). Representatives of the Emberá-Wounaan and Akha communities drew attention to their dialectical relationship with nature based on ecocentric principles contravening the anthropocentric values dominant in the Global North (see, e.g., Benton 1998; Van Uhm 2017; Goyes et al. 2021). Ecocentric values are embedded in the ecophilosophies of the Emberá-Wounaan and Akha communities, and both groups stressed that humans are socially and ethically responsible for respecting the value of ecosystems and its living creatures (Goodman 1997; Halsey and White 1998; Velásquez Runk 2017).

Emberá and Wounaan shamans explained that their culture is based around jai, which are forces manifested in animals, plants and humans. These forces are part of nature and Emberá-Wounaan life and society and stem from an original closed singularity containing everything that exists, which was separated in primordial times (Sepúlveda López de Mesa 2008). The Emberá-Wounaan are emphatic in their belief that spirits manifest themselves in the form of people or animals that inhabit the water, the forest, or the "underworld," 
several of which are guardians of these places (Velásquez Runk 2017). The Akha culture, known as Akhazang, is embedded in polytheism-animism combined with ancestor worship. The forests around their villages are integral to Akha life and spirituality as they provide food, water and medicinal plants. The forests contain many plants that are essential for Akha rituals and ceremonies, and ancestors provide blessings in the form of abundant harvests, animals, fertility and good health (Goodman 1997), meaning that the relationship between Indigenous people and nature is based on a balance between coexistence and symbiosis, rather than exploitation. Virtually every tree species of the forests around Akha villages is important in their lives (see Durno et al. 2007). This is in line with earlier representations that idealize Indigenous communities as being close to nature or encapsulating the primordial essence of ecological wisdom (see, eg., Morris 1981).

Because of the natural "resources" on their lands, Indigenous people have been subjected to acts of dispossession, forced displacement and land grabbing by organized crime groups seeking to increase their wealth and expand their power (Brisman and South 2018; Van Uhm 2020a, b). Environmental degradation is often linked directly to the victimization of human communities. Representatives of the Emberá-Wounaan and Akha communities described unlawful practices of land grabbing by a few powerful people using small, armed groups to displace entire Indigenous communities from their land. On other occasions, the Emberá communities in the municipalities of Acandí and Unguía have been forced to leave because the jungles around their land either have disappeared, have become heavily polluted by mining, or have been disturbed by the cocaine trade. An Emberá chief near Santa María La Antigua de Darién explained that their drinking water comes from polluted rivers and that without forests, they lack essential food and medicines. Poverty is widespread because of the absence of alternative means for income (Fernández and Robertson 2011; Jaeger 2015). Thus, even though these communities have an abundance of natural resources, they are disadvantaged (Goodman 1997; World Bank 2014).

Representatives of the Emberá-Wounaan and Akha communities explained that they may welcome organized crime groups because of economic opportunities in opium production and coca cultivation. At the same time, organized crime groups are looking for people who can find specific natural products, including gold, hardwood, or different species of wildlife. The commodification of natural resources by the respective dominant groups has thus created a form of ecological disorganization on a micro-level, as the extraction of natural resources has gradually become a threat to Indigenous peoples' cultural and social lives. Increased deforestation leads to the erosion of the land and lower water levels along the rivers, which further impedes the infrastructure; with gold mining and coca cultivation, the waters become increasingly polluted, which affects the fish population, the ecosystem, and the health of the Indigenous people (Van Uhm 2020c). Therefore, the dialectical relationship that people living in the region have had with nature and their dependency on it for survival must be considered when holding Indigenous people accountable for environmental degradation as an inherently harmful activity. On the one hand, they are aware of the environmental degradation and the changes in biodiversity caused by the destructive (illegal) trades. On the other hand, they perceive the economic value of natural resources in the context of a lack of other legal job opportunities and the loss of opportunity to live in traditional ways. It seems that some Indigenous communities are caught in a vicious cycle where they need to engage in illegal activities because of the lack of regular jobs, yet access to the legal market is hampered by their illegal activities. 


\section{Caught in the Trade: Isolation, Extortion and Protection}

The attractiveness of the Darién jungle and the Golden Triangle for organized crime groups may also emerge from the power vacuum created by the absence of state institutions (Blok 1974; Varese 2011). For example, the political economy of organized crime groups can involve controlling goods and services and providing protection to the local communities (Skaperdas 2001). In both cases, national and international NGOs and national institutions with financial resources have not been able to send their representatives, such as doctors, lawyers and social workers because of the difficulty in accessing these areas and the presence of armed actors in them. Therefore, such remote regions have been the perfect outlets for land grabbing and the illegal exploitation of natural resources in the past decades- to such extent that permission is required from certain organized crime groups to be allowed to enter some of the visited areas.

This traditional form of territorial control is immediately visible through the physical presence of armed criminal groups among Akha communities involved in opium trade in Shan State in Myanmar (Burma). A chief of one of the non-state armed groups near the town of Kengtung stated that the Akha consider the government to be the main problem in the area and therefore they act as protectors of the Indigenous community. He clarified that protection is important due to the opium cultivation by the Akha and the repressive policies of the Burmese government because they would both benefit from the profits. Even though some Akha complained about their small profits, others were thankful for the social control and protection offered by the dominant groups, given the government's lack of support. Furthermore, a part of the border area of Myanmar (Burma) with China is under the control of non-state armed groups, such as the United Wa State Army (UWSA) and the National Democratic Alliance Army (NDAA), meaning that negotiation with them is recommended in order to transport goods into China. In the past decades, these groups have been highly involved in the cultivation of opium poppy and they have regulated the trade through border control and taxes. ${ }^{4}$ A collaborative relationship with armed criminal groups is visible in the trade of high value goods, such poppy for opium or big cat products (Van Uhm and Wong 2021). The Akha negotiate with their "trade partners" and they have to pay a tax to the dominant groups, which is estimated at around $10 \%$ of the value of the traded goods. Such crime groups exert their power over the Akha, however, by organizing most of the trade that takes place.

In Darién, the type of control that organized crime groups exert on local communities takes the form of extortion. This parasitical relationship means that Indigenous people pay protection money or taxes for the goods they want to trade along specific rivers, including parts of the Cacarica River in Colombia. For example, the Colombian Gulf Clan, a drug cartel and right-wing neo-paramilitary group, has positioned itself in the areas where Indigenous communities live, claiming that social protection is needed because of a lack of governmental institutions (Van Uhm 2020c). A member of the Colombian Gulf Clan explained that the group has a deep respect for the lives and cultural expressions of the Indigenous people. He clarified that because the economic opportunities are limited and the Colombian state has no presence in the area, the Indigenous people need protection and social and sustainable projects in order for there to be peace and justice. This illustrates

\footnotetext{
${ }^{4}$ In the late 1990s and 2000s, the UWSA and NDAA declared an opium ban in parts of their territory, which destroyed the livelihoods of poor opium farmers and sparked widespread food shortages. Non-state armed groups relocated ethnic Akha civilians by force from the special regions.
} 
how organized crime groups have a habit of interacting with their social environment, instead of operating in a social vacuum (van de Bunt et al. 2014). It also shows, however, how organized crime groups replace state institutions and their services-from which Indigenous people often feel disconnected-via a system of patronage and coercive partnerships (Albanese 2010; Blok 1974).

According to the Indigenous people in Darién, criminal groups have been able to expand their drug trafficking routes and increase coca production in their territory. In addition to drugs, an Indigenous chief of a small Emberá village in the middle of coca cultivations near Acandí in Colombia explained how the increasing presence of backhoe excavators, used to extract gold illegally, not only affects the water and other environmental resources of their territory, but also their ethnic rights. He clarified that organized crime groups bring machines for mining and that the development of infrastructure in the ancestral territory had not been agreed upon previously with the community. Moreover, the Colombian Gulf Clan has imposed a curfew of sorts, prohibiting them from leaving their village after 6 p.m. Some Indigenous leaders, Nokoes, did not listen and were killed by the organized crime groups. A Wounaan leader in Katíos National Park explained how his community fears the organized crime groups because their sons are recruited and have been killed when they are no longer of any "use." In response, the Indigenous communities keep the young men out of sight when the organized crime groups arrive. Despite the internal rules, however, young Indigenous people who would like to earn some money join them at the risk of being expelled from their communities. They consider this an opportunity to access power, resources and social prestige in the group (see also Duncan and Suárez 2019; Van Uhm 2020c).

Some Indigenous people become caught in the trade because of a parasitical or coercive relationship that has been established with members of organized crime groups. Leaving the trade would mean that they are in possession of important information regarding cultivation or trafficking, which poses a risk for the organized crime groups. The otherwise unequal relationship in terms of knowledge forces the Indigenous people to continue the trade relations with organized crime groups, who are perceived as protectors, business partners, social justice providers, but also enemies. These examples reflect the social embeddedness of organized crime groups and their de facto territorial control, as well as the changing symbiotic (e.g., collaborative, reciprocal) and antithetical or parasitic relations (i.e., how local communities reject or welcome the organized crime groups, not only because they provide opportunities to work and care for one's family, but also because they provide security) (Blok 1974; Cressey 1969).

\section{Discussion and Conclusion: Perpetrators or Victims?}

Returning to the discussion at the outset regarding how southern criminology and green criminology conceptualize harm and victimization, we would stress that it is important to consider the role of the coloniality of power and the social construction of crime which frames Indigenous people as both offenders and victims in and by criminal justice systems (see generally Cunneen 2018; Sollund 2019; South 2007). Historically, Indigenous groups have been marginalized through racial discrimination common to settler colonialism (Cunneen and Tauri 2016; Goyes 2019; Quijano 2000). This has been illustrated by a tendency to overlook the role of colonial practices in establishing social structures of inequality that 
continue to impact the way in which Indigenous groups are framed in Western discourse, as well as the role of Indigenous knowledge and ecocentric perspectives in the process of understanding environmental crime and harm. This article has shown how colonial legacies may have led or at least contributed to crime in these areas, but also how domination over the Emberá-Wounaan and Akha communities continues by organized (armed) crime groups in the Darién Gap and Golden Triangle, respectively. During conversations, many Indigenous communities pointed to their marginalized position in the context of centuries of oppression and violence by powerful groups-from the colonizers, from the paramilitaries, and from the organized crime groups. By engaging with the Indigenous communities through participant observation and interviews, we have tried to move away from a Western-influenced, top-down approach by presenting their understandings of the complex relationships with these illegal actors.

The colonial, socioeconomic and geopolitical context of the isolated areas of both Emberá-Wounaan and Akha communities, combined with the presence of organized crime groups in their territories, has established the basis for continuous unequal relations. In the hard-to-reach borderlands where these people live, the Indigenous (geographic) knowledge is important for the lucrative business in natural "resources," such as coca, gold, timber, poppy and wildlife. The same borders are important in controlling the trafficking of illegal goods by organized crime groups. Therefore, Indigenous people may be forced to cooperate with organized crime groups in such illegal trade out of fear of repercussions and may be at the highest risk of being caught cultivating drugs or engaging in cross-border smuggling. The lack of legal alternatives and sustainable autonomous projects for income means that some communities eventually collaborate with organized crime groups who can offer them protection and economic opportunities, both of which are lacking in these areas.

The involvement of Indigenous people in the trafficking of natural resources contravenes their ecocentric ecophilosophies. Moreover, the victim-offender relationship, as conceptualized by the state, can act as a determinant of epistemic change because it creates new knowledge about the way people can relate to nature and to each other. This is the source of mixed feelings because modern ideas about the exploitation of nature contradict ancestral beliefs, and while prosperity was considered a blessing under Indigenous worldviews, it may now be regarded as a curse because it brings with it the victimization of the people living in these territories. In other words, Indigenous people have become victims of ecological harm, while the economic benefits of illegal trade are usually enjoyed by others. The changing dynamic of symbiotic and antithetical relations reflects how Indigenous people view organized crime groups not only as enemies because of violence, land grabbing and displacement, but also as business partners, protectors and providers of social justice.

To conclude, this article has shown that the concerns of southern criminology and green criminology meet at the crossroads of the legality-illegality discourse of perpetration and victimization, which is embedded in patterns of colonialism and environmental and social injustices. The new forms of social control resemble colonial practices and perpetuate the marginalization of Indigenous people and the exploitation of their natural environment. Because Indigenous communities lack access to legitimate economic opportunities, as well as state-sponsored education and public health initiatives (Cunneen and Tauri 2016; Goyes 2019), these inequalities are highlighted by organized crime groups to justify their social role as protectors. Moreover, the dialectal relationships Indigenous people have with their natural environment ensure that environmental harm is directly related to the victimization of their human communities. In light of the above, it is crucial to include the "local perspective" in the scientific discourse on the illegal trade in natural resources and 
to move away from the historical eradication of Indigenous epistemologies in the field of criminology.

Acknowledgments First author's research was funded by the Dutch Organization for Scientific Research (NWO): 016.Veni.195.040. Research project: "The Diversification of Organized Crime into the Illegal Trade in Natural Resources."

Open Access This article is licensed under a Creative Commons Attribution 4.0 International License, which permits use, sharing, adaptation, distribution and reproduction in any medium or format, as long as you give appropriate credit to the original author(s) and the source, provide a link to the Creative Commons licence, and indicate if changes were made. The images or other third party material in this article are included in the article's Creative Commons licence, unless indicated otherwise in a credit line to the material. If material is not included in the article's Creative Commons licence and your intended use is not permitted by statutory regulation or exceeds the permitted use, you will need to obtain permission directly from the copyright holder. To view a copy of this licence, visit http://creativecommons.org/licenses/by/4.0/.

\section{References}

Albanese, J.S. (2010). Organized crime in our times. Abingdon, Oxon, UK, and New York: Routledge.

Anderson, C.L.G. (1911). Old Panama and Castilla Del Oro. Washington, DC: Press of the Sudwarth Company.

Anthony, T. (2013). Indigenous People, Crime and Punishment. Abingdon, Oxon, UK, and New York: Routledge.

Ballvé, T. (2020). The frontier effect: State formation and violence in Colombia. Ithaca, NY: Cornell University Press.

Beirne, P., \& South, N. (Eds.) (2007). Issues in Green Criminology: Confronting harms against environments, humanity and other animals. Cullompton, Devon, UK: Willan.

Benton, T. (1998). Rights and justice on a shared planet: More rights or new relations?. Theoretical Criminology, 2(2), 149-175.

Bernatzik, H.A. (1970). Akha and Miao: Problems of Applied Ethnography in Farther India. New Haven, CT: Human Relations Area Files.

Blok, A. (1974). The mafia of a Sicilian village, 1860-1960. A study of violent peasant entrepreneurs. Oxford: Basil Blackwell.

Brisman, A., \& South, N. (2018). Environment, conflict and profit: Harmful resource exploitation and questionable revenue generation. In Spapens, T., White, R., Van Uhm, D.P., \& Huisman, W. (Eds.) Green Crimes and Dirty Money (pp. 19-41). Abingdon, Oxon, UK, and New York: Routledge.

Brisman, A., \& South, N. (2020). Routledge International Handbook of Green Criminology. Second edition. Abingdon, Oxon, UK, and New York: Routledge.

Broadhurst, R. (1999). Crime, justice and Indigenous peoples: The "new justice" and settler states. Australian and New Zealand Journal of Criminology, 32(2), 105-107.

Broadhurst, R.G. (2002). Crime and Indigenous People. In Graycar, A., \& Grabosky, P. (Eds.), Handbook of Australian Criminology (pp. 256-280). Melbourne, VIC: Cambridge University Press.

Carrington, K., Hogg, R., \& Sozzo, M. (2016). Southern Criminology. The British Journal of Criminology, 56(1), 1-20.

Carrington, K., Hogg, R., Scott, J., \& Sozzo, M. (2018). Criminology, Southern Theory and Cognitive Justice. In Carrington, K., Hogg, R., Scott, J., \& Sozzo, M. (Eds.), The Palgrave Handbook of Criminology and the Global South (pp. 3-18). Cham, CH: Palgrave Macmillan.

Carrington, K., Dixon, B., Fonseca, D., Goyes, D.R., Liu, J., \& Zysman, D. (2019). Criminologies of the Global South: Critical Reflections. Critical Criminology: An International Journal 27(1), 163-189. https://doi.org/10.1007/s10612-019-09450-y.

Chin, K. L. (2007). Into the thick of it: Methodological issues in studying the drug trade in the Golden Triangle. Asian Journal of Criminology, 2(2), 85-109.

Chin, K.L. (2009). The Golden Triangle: Inside Southeast Asia's Drug Trade. Ithaca, NY: Cornell University Press.

Connell, R. (2007). Southern Theory: The global dynamics of knowledge in social science. Abingdon, Oxon, UK, and New York: Routledge. 
Cressey, D.R. (1969). Theft of the nation: The structure and operations of organized crime in America (Vol. 174). New Brunswick, NJ, and London: Transaction Publishers.

Cunneen, C. (2007). Criminology, Human Rights and Indigenous Peoples. Sociology of Crime, Law and Deviance, 9, 243-265.

Cunneen, C. (2018). Indigenous Challenges for Southern Criminology. In Carrington, K., Hogg, R., Scott, J., \& Sozzo, M. (Eds.), The Palgrave Handbook of Criminology and the Global South (pp. 19-42). Cham, CH: Palgrave Macmillan.

Cunneen, C., \& Tauri, J. (2016). Indigenous Criminology. Bristol, UK: Policy Press.

Cunneen, C., \& Tauri, J. (2017). Indigenous Criminology. In A. Brisman, E. Carrabine, \& N. South (Eds.), The Routledge Companion to Criminological Theory and Concepts (pp.306-310). Abingdon, Oxon, UK, and New York: Routledge.

Duffy, R. (2010). Nature crime: How we're getting conservation wrong. New Haven, CT: Yale University Press.

Duncan, G., \& Suarez, C. (2019). The threat of organized crime in post-conflict Colombia. In Meernik, J., DeMeritt, J. H., \& Uribe-López, M. (Eds.), As war ends: What Colombia can tell us about the sustainability of peace and transitional justice (pp. 113-133). Cambridge, UK, and New York: Cambridge University Press.

Durno, J.L., Deetes, T., \& Rajchaprasit, J. (2007). Natural forest regeneration from an Imperata Fallow: The case of Pakhasukjai. In Cairns, M. (Ed), Voices from the Forest: Integrating Indigenous Knowledge into Sustainable Upland Farming (pp. 122-136). Washington, DC: Resources for the Future.

Forbes, A.D. (1997). The Haw: Traders of the Golden Triangle. London: Teak House.

Formoso, B. (2010). Zomian or zombies? What future exists for the peoples of the Southeast Asian Massif?. Journal of Global History, 5(2), 313-332.

Gambetta, D. (1993). The Sicilian Mafia: The Business of Private Protection. Cambridge, MA, and London: Harvard University Press.

Gisborne, L. (1853). The Isthmus of Darién in 1852: Journal of the expedition of inquiry for the junction of the Atlantic and Pacific Oceans. London: Saunders and Stanford.

Goldman, E.A. (1920). Mammals of Panama (with Thirty-nine Plates). Washington, DC: Smithsonian Institution.

Goodman, J. (1997). The Akha: Guardians of the forest. Chiang Mai, TH: Asia Film House.

Goyes, D.R. (2019). Southern Green Criminology: A Science to End Ecological Discrimination. Bingley, UK: Emerald Publishing Limited.

Goyes, D.R. Abaibira, M.A., Baicué, P., Cuchimba, A., Ñeñetofe, D.T.R., Sollund, R., South, N., \& Wyatt, T. (2021). Southern green cultural criminology and environmental crime prevention: Representations of nature within four Colombian Indigenous communities. Critical Criminology: An International Journal. https://doi.org/10.1007/s10612-021-09582-0.

Grosfoguel, R. (2007). The epistemic decolonial turn: Beyond political-economy paradigms. Cultural studies, 21(2-3), 211-223.

Halsey, M., \& White, R. (1998). Crime, ecophilosophy and environmental harm. Theoretical Criminology, 2(3), 345-371.

Harvey, D. (2003). The New Imperialism. Oxford, UK: Oxford University Press.

Heckadon-Moreno, S. (1997). Spanish rule, independence, and the modern colonization frontiers. In Coates, A.G. (Ed), Central America: A natural and cultural history (pp. 177-214). New Haven, CT: Yale University Press.

Herlihy, P.H. (1986). A Cultural Geography of the Embera and Wounan (Choco) Indians of Darién, Panama, with Emphasis on Recent Village Formation and Economic Diversification. LSU Historical Dissertations and Theses.

Idler, A. (2019). Colombia: Organised crime, politics, and convenience. In Allum, F., \& Gilmour, S. (Eds.), Handbook of Organised Crime and Politics (pp. 258-274). Cheltenham, UK, and Northampton, MA: Edward Elgar Publishing.

Karch, S.B. (1999). Cocaine: History, use, abuse. Journal of the royal society of medicine, 92(8), 393-397.

Kleemans, E.R., \& van de Bunt, H.G. (1999). The social embeddedness of organized crime. Transnational Organized Crime, 5(1), 19-36.

Koivurova, T. (2010). Sovereign states and self-determining peoples: Carving out a place for transnational Indigenous peoples in a world of sovereign states. International Community Law Review, 12(2), 191-212.

Koller-Armstrong, L. (2009). This Land is Our Land: Indigenous Rights and Rural Development in Darién, Panama. Flordia A\&M University Law Review 5(2), 219-249.

Lintner, B. (1994). Burma in Revolt: Opium and Insurgency since 1948. Boulder, CO: Westview. 
Lynch, M.J., \& Stretesky P.B. (2014). Exploring Green Criminology Toward a Green Criminological Revolution. Abingdon, Oxon, UK, and New York: Routledge

Lynch, M.J., Stretesky, P.B., \& Long, M.A. (2018). Green criminology and native peoples: The treadmill of production and the killing of indigenous environmental activists. Theoretical Criminology, 22(3), 318-341.

McCoy, A.W. (1972). The politics of heroin in Southeast Asia. New York: Harper \& Row.

Morris, B. (1981). Changing Views of Nature. The Ecologist, 11, 130-137.

Myers, C.W., Daly, J. W., \& Malkin, B. (1978). A dangerously toxic new frog (Phyllobates) used by Emberá Indians of western Colombia, with discussion of blowgun fabrication and dart poisoning. Bulletin of the AMNH, 161(2), 307-366.

Nordenskiöld, E. (1928). The history of biology. New York: Knopf

Osburn, R. (2000). Problems and Solutions Regarding Indigenous Peoples Split by International Borders. American Indian Law Review, 24(2), 471-485.

Paoli, L. (2003). Mafia Brotherhoods: Organized Crime, Italian Style. New York: Oxford University Press.

Passas, N. (2002). Cross-border crime and the interface between legal and illegal actors. In van Duyne, P.C., von Lampe, K., \& Passas, N. (Eds.), Upperworld and Underworld in Cross-border Crime (pp. 11-41). Nijmegen, NL: Wolf Legal Publishers.

Quijano, A. (2000). Coloniality of power and Eurocentrism in Latin America. International Sociology, 15(2), 215-232.

Reclus, A. (1881). Panama et Darién: Voyages d'exploration. Paris: Hachette.

Renard, R.D. (1996). The Burmese connection: Illegal drugs and the making of the Golden Triangle. Boulder, CO: Lynne Rienner Publishers.

Rettberg, A., \& Ortiz-Riomalo, J.F. (2016). Golden opportunity, or a new twist on the resource-conflict relationship: Links between the drug trade and illegal gold mining in Colombia. World Development, 84(C), 82-96.

Reverte Coma, J.M. (2002). Tormenta en el Darién: Vida de los indios chocoes en Panamá. Madrid: Ediciones del Museo, Paleopatología y Criminalística.

Ruggiero, V., \& South, N. (2013). Green Criminology and Crimes of the Economy: Theory, Research and Praxis. Critical Criminology: An International Journal, 21(3), 359-373. https://doi.org/10. 1007/s10612-013-9191-6.

Salmón, E. (2000). Kincentric ecology: Indigenous perceptions of the human-nature relationship. Ecological Applications, 10(5), 1327-1332.

Sauer, C.O. (1966). The Early Spanish Main. Berkeley, CA: University of California Press.

Sepúlveda López de Mesa, R.I. (2008). "Vivir las ideas, idear la vida": Adversidad, suicidio y flexibilidad en el ethos de los emberá y wounaan de Riosucio, Chocó. Antípoda. Revista de Antropología y Arqueología, 6, 245-270.

Singleton, S. (2009). Not our borders: Indigenous people and the struggle to maintain shared lives and cultures in post-9/11 North America. Bellingham, WA: Border Policy Research Institute. Retrieved on July 23, 2021, from https://cedar.wwu.edu/cgi/viewcontent.cgi?article=1105\&context=bpri_ publications.

Skaperdas, S. (2001). The political economy of organised crime: Providing protection when the state does not. Economics of Governance, 2(3), 173-202.

Sollund, R.A. (2019). The crimes of wildlife trafficking: Issues of justice, legality and morality. Abingdon, Oxon, UK, and New York: Routledge.

Sollund, R.A., \& Runhovde, S.R. (2020). Responses to wildlife crime in post-colonial times: Who fares best? The British Journal of Criminology, 60(4), 1014-1033.

South, N. (2007). The "corporate colonisation of nature": Bio-prospecting, bio-piracy and the development of green criminology. In Beirne, P., \& South, N. (Eds.), Issues in Green Criminology: Confronting harms against environments, humanity and other animals. Cullompton, Devon, UK: Willan.

Suman, D. (2007). Globalization and the Pan-American Highway: Concerns for the Panama-Columbia Border Region of Darién-Chocó and its Peoples. The University of Miami Inter-American Law Review, 38(3), 549-614.

Theodossopoulos, D. (2016). Exoticisation undressed: Ethnographic nostalgia and authenticity in Emberá clothes. Manchester, UK: Manchester University Press.

Thoumi, F.E. (1995). Political Economy and Illegal Drugs in Colombia. Boulder, CO: Lynne Reiner Publishers.

Töller, I. (2009). Panama, Cemaco's Anti-colonial Resistance, 1510-1512. In I. Ness (Ed.), The International Encyclopedia of Revolution and Protest (pp. 1-2). Hoboken, NJ: John Wiley \& Sons. https:// doi.org/10.1002/9781405198073.wbierp1142. 
Tooker, D.E. (2012). Space and the Production of Cultural Difference among the Akha prior to Globalization: Channeling the Flow of Life. Amsterdam: Amsterdam University Press.

Van de Bunt, H., Siegel, D., \& Zaitch, D. (2014). The Social Embeddedness of Organized Crime. In Paoli, L. (Ed.), The Oxford Handbook of Organized Crime (pp. 321-339). Oxford, UK: Oxford University Press.

Van Uhm, D.P. (2015). Towards moral principles regarding non-human animals: A green criminological perspective. In De Jong, F. et al. (Eds.), Overarching views of crime and deviancy - Rethinking the legacy of the Utrecht School (pp. 565-588). Den Haag, NL: Eleven International Publishing.

Van Uhm, D.P. (2016). The Illegal Wildlife Trade: Inside the World of Poachers, Smugglers and Traders (Studies of Organized Crime). New York: Springer.

Van Uhm, D.P. (2017). A green criminological perspective on environmental crime: The anthropocentric, ecocentric and biocentric impact of defaunation. Revue Internationale de Droit Pénal, 87(1), 323-340.

Van Uhm, D.P. (2018). Wildlife and laundering: Interaction between the under and upper world. In Spapens, T., White, R., Van Uhm, D., \& Huisman, W. (Eds.), Green Crimes and Dirty Money (pp. 197211). Abingdon, Oxon, UK, and New York: Routledge.

Van Uhm, D.P. (2020a). Wildlife trafficking and criminogenic asymmetries in a globalised world. In Brisman, A., \& South, N. (Eds.), Routledge International Handbook of Green Criminology, Second Edition (pp. 529-542). Abingdon, Oxon, UK, and New York: Routledge.

Van Uhm, D.P. (2020b). Atrocity Crimes and Harm to the Environment: Interrelations between Armed Conflict, Violence, and Ecocide. In Hola, B. et al. (Eds.), Oxford Handbook on Atrocity Crimes. Oxford, UK: Oxford University Press.

Van Uhm, D.P. (2020c). The Diversification of Organized Crime into Gold Mining: Domination, Crime Convergence, and Ecocide in Darién, Colombia. In Zabyelina, Y., \& Van Uhm, D.P. (Eds.), Illegal Mining: Organized Crime, Corruption, and Ecocide in a Resource-Scarce World (pp. 105-146). London: Palgrave Macmillan.

Van Uhm, D.P., \& Nijman, R.C. (2020). The convergence of environmental crime with other serious crimes: Subtypes within the environmental crime continuum. European Journal of Criminology. https://doi.org/10.1177/1477370820904585.

Van Uhm, D.P., \& Wong, R.Y. (2021). Chinese Organized Crime and the Illegal Wildlife Trade: Diversification and Outsourcing in the Golden Triangle. Trends in Organized Crime. https://doi.org/10.1007/ s12117-021-09408-z.

Varese, F. (2001). The Russian Mafia: Private Protection in a New Market Economy. New York: Oxford University Press.

Varese, F. (2011). Mafia movements: A framework for understanding the mobility of mafia groups. Global Crime, 12(3), 218-231.

Velásquez Runk, J. (2007). Political economic history, culture, and Wounaan livelihood diversity in eastern Panama. Agriculture and Human Values, 24(1), 93-106.

Velásquez Runk, J. (2017). Crafting Wounaan landscapes: Identity, art, and environmental governance in Panama's Darién. Tucson, AZ: University of Arizona Press.

Walker, A. (1999). The legend of the golden boat: Regulation, trade and traders in the borderlands of Laos, Thailand, China, and Burma. Honolulu, HI: University of Hawaii Press.

White, R. (2011). Transnational Environmental Crime: Toward an eco-global criminology. Abingdon, Oxon, UK, and New York: Routledge.

White, R. (2014). Environmental harm: An eco-justice perspective. Bristol, UK: Bristol University Press.

Williams, C. (1999). Resistance and Rebellion on the Spanish Frontier: Native Responses to Colonization in the Colombian Chocó, 1670-1690. The Hispanic American Historical Review, 79(3), 397-424.

Williams, V.R. (2020). Indigenous Peoples: An Encyclopedia of Culture, History, and Threats to Survival. Santa Barbara, CA: ABC-CLIO, LLC.

World Bank. (2014). Towards sustainable peace, poverty eradication, and shared prosperity. Hacia la paz sostenible, la erradicación de la pobreza y la prosperidad compartida). Número del informe ACS10900. Washington, DC: World Bank.

Wright, A. (2014). Opium and Empire in Southeast Asia: Regulating Consumption in British Burma. Cham, $\mathrm{CH}$ : Palgrave Macmillan.

Publisher's Note Springer Nature remains neutral with regard to jurisdictional claims in published maps and institutional affiliations. 